\title{
The Travels of St. Thomas in the East and the Migration of His Name
}

\author{
Robert James \\ University of Wales, Newport
}

\section{Introduction}

A week later his disciples were again in the house, and Thomas was with them. Although the doors were shut, Jesus came and stood among them and said, 'Peace be with you.' Then he said to Thomas, 'Put your finger here and see my hands. Reach out your hand and put it in my side. Do not doubt but believe.' Thomas answered him, 'My Lord and my God!' (John 20.26-28, NRSV translation).

This scene from the Gospel of John is the last sighting that many Christians in the West will have of the Apostle Thomas. Although Thomas' encounter with the risen Christ is emblematic of so much about the nexus of faith and doubt that it is often brought to mind, this is generally all that is known of Thomas: that he doubted and then became convinced by his meeting with Jesus. Beyond this, Thomas fades from view. A few may have heard tell of how he apparently travelled to India and founded churches there. But this story is mysterious and full of mythology and it is not well known. Maybe this is to be expected. If it is true that Thomas travelled east, this would inevitably have removed him from the centres of Greek and Roman influence, which is where the early histories of the Church were being written and where selection took place of the texts that were to make up the New Testament. So today, it is hardly surprising that the tales of Thomas' travels are not well known in the west. They do not feature in the New Testament and the average Christian does not look outside of this (rather limited) account of the goings on of the very early church. In this paper, we will explore various Thomas traditions. We will assess the veracity of these traditions and suggest a possible reconstruction of the history of St. Thomas' travels. We will begin with the third century book the Acts of Thomas and then examine a separate and different account of his travels from southern India. We will conclude with a suggestion 
of what Thomas actually did in terms of travel to the East that can account for the differences in the two traditions about his travels.

\section{The Acts of Thomas}

There are two principle texts that bear the name of Thomas, but only the Acts of Thomas makes reference to his missionary work. In the first place, it is worth mentioning the most famous text to bear the Apostle Thomas' name, the Gospel of Thomas. This is mentioned simply to remove it from the reader's mind as having any connection with the question at hand, namely, what actually happened to Thomas. Although the Gospel of Thomas is of enormous interest, it is entirely spiritual and probably originated from a small ascetic group. It may or may not be historically associated with Thomas in some way, although probably not, and in any case sheds little to no light upon his actual movements. ${ }^{1}$

However, the Acts of Thomas is a far more useful text for our purpose. This book, although late, being written in the third century, purports to relate Thomas' actual movements. Possibly the best English edition of the Acts of Thomas is that by A. F. J. Klijn. ${ }^{2}$ This edition includes a good text critical introductory chapter as well as other introductory chapters which attempt to set the scene of the book's composition. Klijn notes that 'before the composition of these Acts, no traditions are available according to which Thomas went to India. 3 By this, he means that nothing had been written down before the third century (at least nothing extant). It is of great value to point out the fact that it is extremely unlikely that the author of these Acts dreamt the whole affair up on his own. We have to assume that there was a tradition, or more likely a selection of traditions, which the author received in order to write the book. One significant result of this is that we may, within the Acts of Thomas, have a number of conflated traditions, which originally told differing stories. If there are different histories of Thomas that have been conflated together, this will clearly impact on attempts to establish what he actually did and where he actually went.

As well as pondering the text's use of source materials, it is also worth contemplating the purpose of its composition and in this case, it appears to be composed primarily as a didactic document. Specifically, the document teaches doctrines that are certainly ascetic and quite possibly ideas that come from the Manichaeans or some another Gnostic sect. In keeping with this, Farquhar asserts that the Acts of Thomas was written primarily as a

\footnotetext{
${ }^{1}$ For a good translation of both the Coptic text and the Greek fragments (and also a commentary, which it is suggested the reader critically evaluates as they progress though it), see Richard Valantasis, The Gospel of Thomas, London: Routledge, 1997.

${ }^{2}$ A. F. J. Klijn, The Acts of Thomas, Leiden: Brill 1962.

${ }^{3}$ Ibid., 27.
} 
polemic against marriage, in that marriage is unspiritual and therefore not the highest way of life. ${ }^{4}$ He probably goes too far in singling this out as the single doctrinal cause of its writing. However, it is an interesting observation and the question of the worth of marriage (or at least sexual intercourse) does occur within the Acts. A more general assessment of the doctrine within the Acts of Thomas is made by Klijn, and, although he spends some time on marriage, there are other areas he also looks at, enabling the teaching on marriage to be set within a wider doctrinal context. ${ }^{5}$ The principle areas of doctrine, apart from marriage, which Klijn sees in the Acts are the relationship of the soul to the body, the relationship of man to God, the salvation of the soul, and Christology. It can actually be seen that the teaching against sexual intercourse is due to the overriding fact of the soul being hampered by the body and the need to overcome these bodily limitations (al la Gnosticism). One further point about theological content should be raised, namely that the author constantly compares Thomas to Jesus. Just one example of this is the manner of his martyrdom, where the similarities with Jesus' death are striking. There can be little doubt that the author of the Acts of Thomas used traditions about Thomas to set his own theology within. Nevertheless, it is very probable that there are historical Thomas traditions worthy of recovery within the work. What we cannot do is go so far as to say is that the historical Thomas taught and did all of what is said of him in his Acts, which was written down at least two hundred years later. $^{6}$ In order to recover genuine traditions about his journeys, it may be necessary to edit out of the text that element of comparison to Jesus' life and also doctrinal points not considered as early as the historical Thomas.

It is now necessary to outline the story presented in the Acts of Thomas. The Acts starts its tale in Jerusalem, shortly after Jesus' resurrection. Thomas and the other Apostles draw lots to decide which of them will evangelise the various parts of the known world. The lot of India falls to Thomas, but he is unwilling to fulfil his role; he says that he will go anywhere for the Lord, but not to India. Jesus appears to a merchant named Habban, the official merchant of King Gundaphar of India, and on the pretext that Thomas is Jesus' slave, sells Thomas to Habban. Habban then takes Thomas to India where he is to build a new palace for the King. Thomas is given vast resources to undertake this task, but he spends the money in helping the poor, claiming that he is building the King a palace in Heaven. The King is outraged and is going to kill Thomas when

\footnotetext{
${ }^{4}$ J. N. Farquhar, 'The Apostle Thomas in Northern India,' in Bulletin of the John Rylands Library, 10 (1926), 80-111, 83

${ }^{5}$ Klijn, Acts of Thomas, 35-7.

${ }^{6}$ Ian Gillman, and Hans-Joachim Klimkeit, Christians in Asia before 1500, Curzon: Surrey, $1999,54$.
} 
his brother falls ill and dies. The King's brother sees the palace in Heaven, built by Thomas for the King, and then returns to life and informs the King. Thomas is of course spared and the King converted. Thomas then goes to another kingdom, that of King Mazdai, which he reaches after several other adventures. He angers this King by teaching complete sexual abstinence, which is followed by an important courtier's wife. The King eventually takes Thomas outside the city and orders four soldiers to kill him. The story ends happily when the King's son is healed by the dust of Thomas' grave and the King is converted.

There are several points to make about the story of Thomas as we have it related in his Acts. In an extensive quote from Enslin in their magisterial work Christians in Asia before 1500, Gillman and Klimkeit point to the impossible nature of Thomas and Habban sailing from Jerusalem to India.? For the tradition recorded in the Acts of Thomas that Thomas left Jerusalem for India have any credibility whatsoever, there must surely be an intermediate stage in the journey which has been missed out by the author of the Acts. Given that the account given of Thomas reaching India in the Acts plainly makes no sense, the most reasonable thing to assume here is that the author of the Acts has removed a section of tradition. The section would have Thomas travelling to a major sea port before going to India. We can say this rather than that the author invented the means of transport, since we can be fairly certain that he would not have invented a plainly silly means of transport. We must therefore assume that Thomas did reach India by sea, and ask where he actually went to catch his ship.

The solution put forward by almost all authorities on Thomas is that he travelled first to Alexandria. It is also generally assumed that it is here that Thomas met with Habban. Farquhar and others have pointed to the fact that many ships, 120 a year, sailed from Egypt to India. Alexandria would have been only about one week away from the largest sea port on the Egyptian East coast and it is principally with Alexandria that India would have traded via this port. Farquhar suggests that Thomas travelled to Alexandria where he converted King Gundaphar's Merchant, Habban. Habban, it is suggested, then requested that Thomas, as Christ's slave (in a Pauline sense), go with him to convert the King and Thomas agreed. Whatever we may think of the circumstances of Thomas' enslavement, Farquhar gives us some very useful details as to how the Monsoon had been discovered and how it took its cargo of ships directly to the mouth of the Indus. ${ }^{8}$ It seems very reasonable that this is indeed the route that Thomas took. This supposition is further supported by the fact that the Acts of

\footnotetext{
${ }^{7}$ Gillman and Klimkeit, Christians in Asia, 160.

${ }^{8}$ Farquhar, 'The Apostle Thomas in Northern India,' 90-6.
} 
Thomas were most probably written at or near Edessa. Although Edessa was keen to assert its Apostolic pre-eminence it is a fact that it was within the Antiochine sphere of influence. Given that St. Thomas was Edessa's 'chosen' Apostle (we will return to this below), and the hostility between Antioch and Alexandria, it is very likely that the author of the Acts of Thomas would have erased the mention of Alexandria from his book. For the time being, we will therefore assume that this is the course of events; Thomas left Jerusalem and travelled to Alexandria where he met, or was enslaved by, Habban. They left Alexandria and were deposited at the mouth of the Indus by the Monsoon.

Having affirmed that Thomas arrived in India, we should now go on to see whether the Acts is right or wrong in its assertion that he then journeyed to the Kingdom of Gundaphar. There is no longer any doubt that the King named as Thomas' master really did exist. In fact, Senior convincingly shows that there were several kings of this name, the name being used in a similar way to Augustus in Rome. He shows how the Gundaphar that we are interested in had the name Sasea. Furthermore, he offers compelling evidence that an inscription from Takhti Bahi naming Gundaphar as King can be dated to $46 \mathrm{AD} .{ }^{9}$ In addition to this, excavations of Taxila show that Gundaphar's palace was exceptionally modest, actually quite small, and it is reasonable to assume that he wanted a grander construction. ${ }^{10}$ Furthermore, there is evidence to show that during the First Century carpenters and the like were being shipped into India to help with building projects. ${ }^{11}$ A King Gundaphar can therefore be seen to have certainly been reigning in $46 \mathrm{AD}$. His kingdom was in the north of India, however, writers of antiquity had a more extended idea of India than we have today and his kingdom included parts of Pakistan and southern Afghanistan as well. If Thomas had landed at the mouth of the Indus he would have had to travel upstream for $1300 \mathrm{mi}-$ les to the cosmopolitan capital city of Taxila. Taxila was the 'Oxford of early India,' with a great University and a great mix of peoples, Hindus, Buddhists, Jains, Zoroastrians and Greek Pagans. ${ }^{12}$ Thomas would have been nothing particularly spectacular in this multi-religious scene.

\section{South to North and Back Again?}

It is at the point where Thomas reaches the Indus and sails up it that we run into a problem. The Church of South India disputes the fact that

\footnotetext{
${ }^{9}$ R. C. Senior, From Gondophares to Kanishka, 1997, 1-10 (Published privately, a copy is held in Cambridge University Library)

${ }^{10}$ Farquhar, 'The Apostle Thomas in Northern India,' 101.

11 Samuel H. Moffett, Christianity in Asia: Volume 1: Beginnings to 1500, San Francisco: HarperCollins, 1992, 32.

${ }^{12}$ Farquhar, 'The Apostle Thomas in Northern India,' 98-100.
} 
Thomas went first to the North. It says that he landed first at Muziris on the Malabar Coast. They say that he founded seven churches and erected seven crosses. He then preached all over India (presumably including in King Gundaphar's kingdom), and even into China, before returning to the South where he was killed at Mylapore by a group of Brahmins, clearly a different tradition from that preserved in the Acts. There are several local songs with accompanying lines of transmission tracing this tradition back 48 generations from the time they were written down in $1601 .^{13}$ If we allow 30 years per generation a quick calculation will take us back to 161 $\mathrm{AD}$. A slight alteration of the figures could place it even nearer to the time of Thomas, and the line of transmission as we have it may not stretch all the way back anyway. On the other hand, it is not possible to independently verify this tradition. Nevertheless, as Moffett points out, just because Gundaphar existed, does not mean that the story in Acts is the most accurate one, or that Thomas ever visited him at all. ${ }^{14}$ We must now assess the southern Indian tradition which is clearly in competition with the Acts in many ways, before deciding which is to be preferred.

The first thing to point out is that there is a way of harmonising the two traditions up to the manner of Thomas' death, which in any case is a martyrdom in both instances. We have already established that the author of the Acts probably did not insert everything that he could have done from the traditions he received. It is therefore possible that he declined to mention the fact that before going to the North, he went to the South. Furthermore, we have no information regarding the location of the kingdom of King Mazdai. If this king reigned over a portion of Southern India, there are very few differences of opinion between the two traditions. Moffett points to archaeological evidence that the supposed tomb of Thomas is genuinely first century ${ }^{15}$ whilst P. Thomas suggests that Thomas would have gone first to the isolated Jewish communities on the Malabar coast who, partly due to their isolation, would have welcomed the idea of the Messiah. ${ }^{16}$ Further in support of the southern Indian Tradition, we may return to our point made earlier about the author of the Acts mirroring Christ in what he says about Thomas. If Thomas' death really were by an angry mob, the author probably would have changed it to being carried out by four soldiers on a hill outside the city, since this is closer to what Christ experienced.

\footnotetext{
${ }^{13}$ Moffett, Christianity in Asia, 34.

${ }^{14}$ Ibid., 30.

15 Moffett, Christianity in Asia, 36.

${ }^{16}$ P. Thomas, Christians and Christianity in India and Pakistan, London: George Allen, 1954.
} 
Although the line of transmission, the oral tradition itself, the archaeology, and the possibility of Jewish converts all appear to bolster the southern Indian tradition, the deeper one looks at it, the more cracks seem to appear. Sharn points to several interesting facts that show problems in the tradition. Firstly, the church at Mylapore is built over the ruins of two old temples, one to Shiva and one of Jain origin. It is therefore possible that the tomb dated to the first century has nothing to do with Christianity, let alone St. Thomas. ${ }^{17} \mathrm{He}$ also finds it unlikely that the Hindus would have killed Thomas, but more likely that the Christians, zealous for their new faith, would have killed the Hindus. He suggests that the references to the "erosion" of the Kapaleeswara Temple by the sea is actually a reference to destruction by the Christians who also destroyed the Shiva and Jain temples. Once they had themselves martyred Hindus, they inverted the events, inventing their own martyr - Thomas. Sharn dates this to the influx of Persian refugees led by a merchant by the name of Thomas in $345 \mathrm{AD} .{ }^{18}$ Sharn may well be correct in a lot of what he says, but he is probably wrong to suggest the invention of the martyrdom of Thomas, because of its independent attestation by the Acts. In addition to this, we all know from events of our time that Hinduism produces its religious extremists just like any other religion, being quite capable of murder. However, this one (biased) source should not rule our judgement overmuch. We must find other sources to corroborate Sharn's evidence, or else find the case not proven.

When in a difficult situation students of the early church should never underestimate the value of Eusebius' The History of the Church, and it proves helpful in this instance. There are two useful passages in Eusebius for our purposes. These are book three chapter one and book five chapter ten. Book three does not mention India, but it does tell us that Thomas was sent to Parthia. Seeing as how the kingdom of Gundaphar was an independent Parthian kingdom, it is quite conceivable that here Eusebius' tradition coincides with that of the Acts (or Acts with Eusebius). Book five provides us with even more useful information. It is here that Eusebius tells of how Pantaenus, the head of the Catechetical School of Alexandria, went to India on a mission, and found the Indians in possession of the Gospel of Matthew given to them by the Apostle Bartholomew. ${ }^{19}$ Modern Christians in South India do not like this and suggest a corruption of Mar Thoma (Bishop Thomas) to Bar Tolmai (the Hebraic form of Bartholo-

\footnotetext{
${ }^{17}$ Ishwar Sharn, The Myth of St. Thomas and the Mylapore Shiva Temple, New Delhi: Voice of India, 1995, 153-9.

${ }^{18}$ Ibid., 5 .

${ }^{19}$ For a good English translation of Eusebius, including introduction and useful appendices, see G. A. Williamson, and Andrew Louth, Eusebius: The History of the Church, London: Penguin Books, 1989.
} 
mew). They also suggest that Pantaenus travelled to the Arabian Peninsula instead of India as we know it today, but which could have legitimately been classed as India by him. Although this is possible, it remains unlikely since Pantaenus' pupils give detailed descriptions of their master's travels and they are manifestly not describing Arabia. ${ }^{20}$ Gillman and Klimkeit suggest that originally, the south of India accepted Bartholomew's mission and the North, Thomas'. However, when the Southern trade routes with Egypt fell into disuse, the South had to look North for guidance, and in time accepted Thomas as their (therefore spurious) founder. ${ }^{21}$

Thus we have to suggest that the Southern Indian tradition is a late tradition not relating to the real founder at all. The best guess we have at Thomas' travels is that he did indeed travel North up the Indus and that he did work for Gundaphar. Importantly, we may also assert that he did not go firstly to the Malabar Coast. These communities were founded by a different apostle, Bartholomew (that is of course, providing that it is the same Bartholomew who was an apostle, we should allow for the possibility that this Bartholomew was simply a disciple). However, we have not ruled out the possibility, beyond reasonable doubt, that Thomas was martyred in the south. Thus far we only have Sharn's word against it, and this is plainly not enough. Indeed, the martyrdom of Thomas could be just the fact which confused the south Indian conception of who carried out the initial evangelisation of the area.

It can be estimated that Thomas was forced to flee Taxila at some point between AD 50 and 60. The Kushans overran Gundaphar's kingdom at some point during this time and razed the capital to the ground. ${ }^{22}$ We may assume that the kingdom's destruction was the cause of Thomas' departure, but we have no firm evidence as to which direction he travelled in. Here of course the southern Indian tradition reasserts itself, claiming that King Mazdai ruled in the south during this period. In support of this, Farquhar suggests that the author of the Acts of Thomas has used names familiar to him to set the Thomas story within, Mazdai being the name of a Satrap under Darius III. ${ }^{23}$ He also suggests that for Thomas to have travelled south would have made sense since he would still be dealing with Hindus. ${ }^{24}$ This argument falls apart when we consider that no matter where Thomas went, even as far as Greece, he would not encounter any unfamiliar religion since Taxila was so cosmopolitan. Fleet suggests that the

\footnotetext{
${ }^{20}$ Moffett, Christianity in Asia, 38.

${ }^{21}$ Gillman and Klimkeit, Christians in Asia, 167.

${ }^{22}$ J. N. Farquhar, 'The Apostle Thomas in Southern India,' in Bulletin of the Jobn Rylands Library, 11 (1927), 20-50, 21.

${ }^{23}$ Ibid., 33.

${ }^{24}$ Ibid., 25.
} 
name King Mazdai is a corruption of the name King Vasudeva of Mathura under Zoroastrian influence. ${ }^{25}$ Although Vasudeva was a contemporary of Gundaphar, this seems to be clutching at straws a little, and there is no real reason to suppose that this rather than any number of other names is the one to be corrupted. However, in respect to the Zoroastrian influence, it is worth noting that Thomas would have been very at home talking to the Zoroastrians, since there was a large Fire Temple in Taxila. Interestingly the Zoroastrian's God is called Ahura Mazda. Let us suppose for a moment that Gundaphar's Kingdom having fallen, Thomas went north into Parthia proper, to the Zoroastrians. If he really did attempt to convert high ranking officials or their wives, it is likely that he would have been executed. If this is correct, it is easy to see how the author of the Acts of Thomas could have received a tradition that he was killed by the followers of the Lord Mazda, or by King Mazdai. If this is accurate, it is also quite possible that Thomas' followers could have been at least partially responsible for the evangelisation of Edessa, even if this was only in the form of strengthening an already existent community. This would account for the reverence felt by Edessa toward the saint. This would also account for the tradition that Thomas sent letters to Edessa to tell of his successes. ${ }^{26}$

\section{Thomas' Name: a Southwards Migration}

If the above is correct, and although it seems the most likely explanation of events it is by no means certain, we must finish our exploration of St. Thomas' travels by asking how his name travelled so far south. There are two possible answers to this question. The first answer to this particular question is something which we have already come across in Sharn's refutation of the southern Indian tradition, namely that the Thomas traditions came with the influx of refugees led by Thomas the merchant. Gillman and Klimkeit give two possible dates for the influx, 345 and 745 . It is noticeable that the date of 345 ties in with the persecution of Christians by the Parthian ruler Shapur III. ${ }^{27}$ If Thomas had travelled to Parthia, where he had founded a church, and then his later followers had fled the country, this could well explain the emergence of the southern Indian traditions. Corroboration for this argument is the fact that the Hindu ruler welcomed the Christians as they fulfilled a vital trading role in his kingdom. ${ }^{28}$ This suggests that any Christian community that was already in existence (presumably relating to Bartholomew and Pantaenus) was small and weak

\footnotetext{
25 J. F. Fleet, 'St. Thomas and Gondophernes,' in The Journal of the Royal Asiatic Society, 37: 2 (1905), 223-36, 235.

${ }^{26}$ Gillman and Klimkeit, Christians in Asia, $161 \mathrm{f}$.

${ }^{27}$ Ibid., 163.

${ }^{28}$ Ibid., 169.
} 
and that its traditions would easily be supplanted. However, as time went on, the displaced community probably adapted its traditions to fit its new home, the older traditions being preserved by the author of the Acts.

The other answer as to how Thomas' name was preserved in the South is that upon the destruction of Gundaphar's kingdom, Thomas' followers scattered. Although he went north, some of them headed south. If contact was maintained between the two groups until the time of Thomas' death, it is easy to see how the Southern group could make subtle alterations to the story of Thomas' Martyrdom to make it fit the local situation. It is conceivable that there were then two rival Christian groups in the south, one of which (Thomas' group) eventually totally supplanted their brethren (Bartholomew's group). The Acts would still maintain the older, more historical traditions in this instance. The second situation may be more likely, in view of the fact that Thomas' body is supposed to have been taken to Edessa in the Second Century from South India, ${ }^{29}$ and the fact that Gillman and Klimkeit prefer the later date of 745 for the arrival of the refugees.

Throughout this paper we have seen a constant tension between seemingly rival church traditions. We have seen how the historical facts can be reconstructed from these differing traditions, but also how different scholars have different opinions about just what these facts may be. The most convincing reconstruction seems to be that Thomas left Jerusalem to travel to Alexandria. From Alexandria he travelled the short distance to the Egyptian East coast. From there he travelled with the Monsoon, north east to the mouth of the Indus. He then travelled up the Indus to the northern Indian Kingdom of Gundaphar, where he preached his faith. Upon the destruction of Gundaphar's kingdom, he travelled north into Parthia proper and preached to the Zoroastrians. He overstepped the limits of the Parthians and was martyred for it probably by an angry mob, but maybe by soldiers, we shall never know for certain. During his time in Parthia, or soon after his martyrdom, his disciples helped evangelise Edessa and added strength to the community already there. It is possible that several hundred years later some of his followers fled south to escape persecution, taking their traditions with them. They reached the southern tip of India, where they bolstered the already existent Christian communities, however, in so doing, they supplanted the local traditions with their own. These traditions morphed over time, so that Thomas was their local founder, rather than their geographically more distant one. A second possibility is that some of Thomas' followers arrived in the south after he fled north. In this model, the southern Christians would have maintained contact with their northern brothers for a time and then their traditions would have

\footnotetext{
${ }^{29}$ Farquhar, 'The Apostle Thomas in Northern India,' 83.
} 
undergone a similar transformation, as already discussed, with Thomas again becoming the local founder.

\section{Conclusion}

It is curious, yet strangely satisfying, to reach a conclusion whereby although the actual traditions of the southern Indian community are held to be unhistorical in their detail (apart from the manner of Thomas' death), the central fact that they were founded by St. Thomas remains intact. Although Thomas probably never went to southern India, we can still say that he was the founder of the community which subsists there to this very day, for without Christians converted by him arriving, the community would be quite different and may have ceased to exist. We can say that Thomas probably worked in the north and show why he was respected at Edessa and yet also how, through a concatenation of circumstances, he founded the southern community as well.

\section{References}

Farquhar, J. N., 'The Apostle Thomas in Northern India,' in Bulletin of the John Rylands Library, 10 (1926), 80-111.

Farquhar, J. N., 'The Apostle Thomas in Southern India,' in Bulletin of the John Rylands Library, 11 (1927), 20-50.

Fleet, J. F., 'St. Thomas and Gondophernes,' in The Journal of the Royal Asiatic Society, 37: 2 (1905), 223-36.

Gillman, Ian, and Hans-Joachim Klimkeit, Christians in Asia before 1500, Curzon: Surrey, 1999.

Klijn, A. F. J., The Acts of Thomas, Leiden: Brill 1962.

Moffett, Samuel H., Christianity in Asia: Volume 1: Beginnings to 1500, San Francisco: HarperCollins, 1992.

Senior, R. C., From Gondophares to Kanishka, 1997, 1-10 (Published privately, a copy is held in Cambridge University Library).

Sharn, Ishwar, The Myth of St. Thomas and the Mylapore Shiva Temple, New Delhi: Voice of India, 1995.

Thomas, P., Christians and Christianity in India and Pakistan, London: George Allen, 1954.

Valantasis, Richard, The Gospel of Thomas, London: Routledge, 1997

Williamson, G. A., and Andrew Louth, Eusebius: The History of the Church, London: Penguin Books, 1989. 